\title{
SHEAR STRENGTH OF RC DEEP BEAM PANELS - A REVIEW
}

\author{
J. Leon Raj ${ }^{1}$, G. Appa Rao ${ }^{2}$ \\ ${ }^{I}$ Research Scholar; Department of Civil Engineering, Indian Institute of Technology Madras, Chennai-600036 \\ ${ }^{2}$ Professor, Department of Civil Engineering, Indian Institute of Technology Madras, Chennai-600036
}

\begin{abstract}
Behaviour of RC beam panels is influenced by several factors. An alternative for conventional beam is $3 D$ steel wire precast panel to behave as deep beam in various locations of RC building systems. Understanding the influence of factors involved on behaviour and strength is needed. The factors to be discussed include; compressive strength of concrete, percentage of tension reinforcement, quantity and distribution of vertical and horizontal web reinforcement, aggregate interlock, shear span-to-depth ratio, distribution of loading, side cover, and depth of beam. The influence of above parameters on the shear strength of reinforced concrete deep beams has been reviewed.
\end{abstract}

Keywords: Deep beams, Shear strength, 3D panels, distribution of reinforcement.

\section{INTRODUCTION}

A major challenge in every tall building construction is to achieve adequate column free space in the lowermost storey either for parking or storage facility. To achieve sufficient dwelling room size as per architectural design in the upper stories, vertical element so-called floating column is endowed. Its terminal level rests on the transfer girder which acts as a point load. In view of ample shear strength, deep beams are primarily recommended as transfer girders. These members transfer loads through loading face to supports in the transverse direction. The deep horizontal members predominantly fail in shear rather than flexure. These beams are characterized with small span-to-depth ratio. Pile caps, corbel, brackets, foundation walls and off-shore structures are few examples of RC deep beams.

Web reinforcement plays a vital role in enhancing the shear capacity and mode of failure. It is unclear that IS 4562000 provisions for minimum web reinforcement ensures ductile failure and inherently satisfies the serviceability criteria. In addition, there is a lack of comprehensive provision for the design and prediction of shear-capacity of RC deep beams. Motivation for this review is to understand the influencing parameters of deep beams on strength and serviceability aspects.

3D steel wire sandwich panels enunciated as light weight panels comprise of concrete-polystyrene-concrete layers. Either side of the polystyrene, concrete cover is reinforced with steel wire mesh. 3D panels can be used as an alternative for structural members such as walls, beams and slabs. Advantages over the conventional construction system are eco-friendly, light weight, fast construction, cost effective, thermally and acoustically insulated. In addition to the aforementioned conspicuous advantages, the sandwich panel has the following advantages in structural behaviour. Hereby, advantages of 3D panel in structural behaviour aspect are explained in comparison with deep beams and shear walls vis-a-vis minimum percentage of web reinforcement mentioned in code. As per ACI Committee 2008 , minimum percentage of horizontal and vertical web reinforcement for deep beams is 0.15 and 0.25 . Minimum web reinforcement for shear wall in orthogonal directions is $0.25 \%$ (Murty, 2005).

3D panels have well distributed steel wire mesh inherently satisfying the minimum web reinforcement criteria. Integral and diaphragms action are two major research issues to be studied. Steel wire meshes on the either side of the polystyrene are fastened with inclined or $90^{\circ}$ steel connectors can accomplish the integral action (Carbonari et al. 2012).

\section{DEFINITION OF RC DEEP BEAMS}

A beam is defined as a deep beam in which either the clear span is equal to or less than four times the overall depth, or the concentrated loads are within a distance equal to or less than two times the depth from the face of support (ACI Committee 318, 2008).

According to IS 456-2000 a beam shall be deemed to be a deep beam when the ratio of effective span-to-overall depth, $\frac{1}{D}$ is less than:

1)2.0, for simply supported beam; and

2)2.5, for a continuous beam

Though different codes define deep beams in different clear span-to-depth ratios, as a general rule deep beams are recognized by their relatively small span-to-depth ratio.

\subsection{Effect of Compressive Strength of Concrete}

Compressive strength of concrete has a predominant role in structural strength of deep beams. As show in Fig. 1, compressive strength of concrete increases the nominal shear stress (Mphonde and Frantz, 1984). 


\section{Influence of compressive strength of concrete}

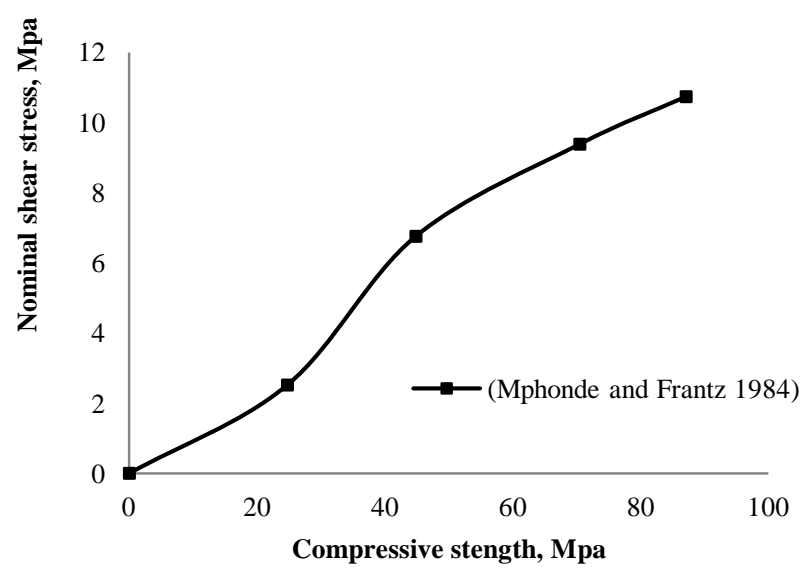

Fig. 1 Influence of compressive strength of concrete on nominal shear strength

Compression softening effect (Vecchio et al. 1993) is nothing but cracked reinforced concrete in compression exhibits lower strength and stiffness than uniaxially compressed concrete. This effect influences the element strength, ductility and load-deformation curve. Parameter influencing the compression softening effect was degree of cracking that is measured by principal tensile strain. The load path, crack orientation relative to the reinforcement, crack rotation and type of reinforcing bar had no effect on the softening effect under monotonic loadings. The strength prediction of element might be overestimated if so-called compression softening effect was neglected or underestimated. Besides, the strength reduction coefficient for the main strut was found to decrease with the angle of inclination of the strut (Matamoros and Wong 2003).

\subsection{Effect of Tension Reinforcement}

Increase in the reinforcement ratio results in increase in ultimate load (Fig. 2 (a)), energy absorption index, number of cracks but then, decrease in ductility (Fig. 2 (b)), length and width of the crack. Beams with high tension reinforcement ratio endure the load beyond the elastic stage with less deflection. There is no strut formation if the percentage of tension reinforcement is less than that of the code provision. On the other hand compression strut fails when the tension capacity is high (Mohammadhassani et al. 2012).
Influence of percentage of tension reinforcement

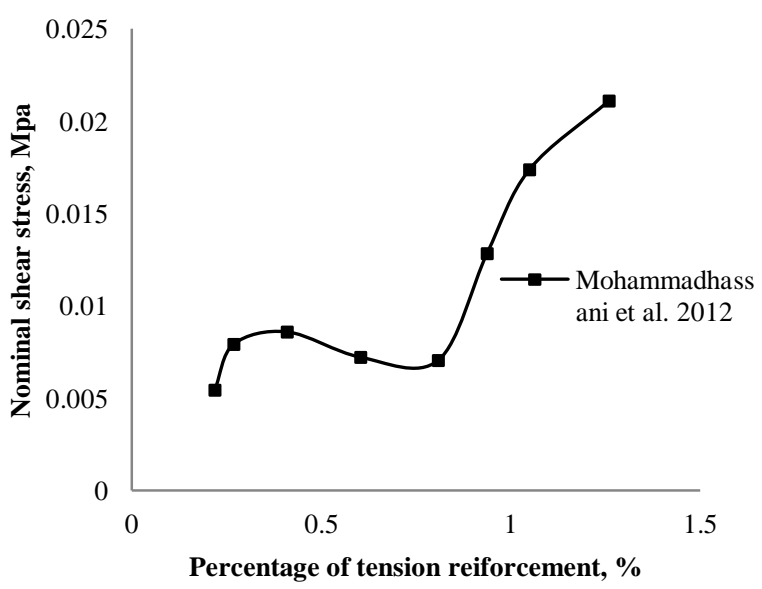

(a)
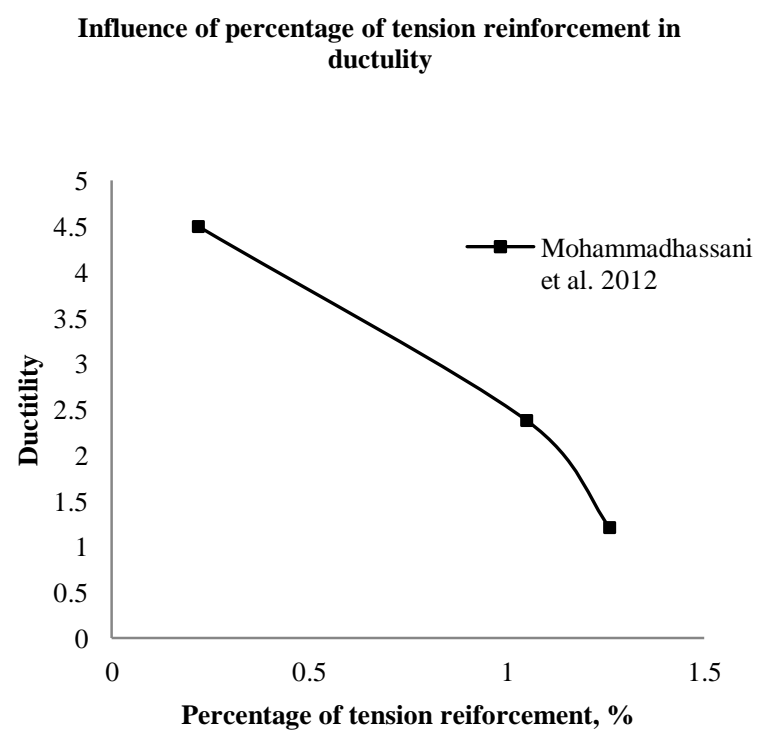

(b)

Fig. 2. Effect of tension reinforcement on (a). shear strength and (b). ductility.

\subsection{Effect of Vertical Web Reinforcement}

Minimum strut reinforcement needs to be provide to avoid splitting failure in struts. No clear concensus about the role of transverse reinforcement in bottle shaped struts in ACI code. Catastrophic failure could be avoided by providing minimum transverse reiforcement (Sahoo et al. 2009). Steel fibers (Madan et al. 2007) or combination of steel fibers and poly propylene fibers (Raj and Rao, 2013) can be used as replacement of web reinforcement 


\subsection{Effect of Horizontal Web Reinforcement}

The horizontal web reinforcement at close spacing near the bottom faces of the beam has been observed to be effective (Smith and Vantsiotis 1983). The shear strength increases with increase in the percentage of web reinforcement (Madan et al. 2007). Both the vertical and horizontal web reinforcement are efficient in resisting the shear capacity of deep beams, but the horizontal shear reinforcement is most effective when aligned perpendicular to the major axis of the diagonal crack (Arabzadeh et al. 2011). Provision of shear reinforcement within the middle region of the shear span can improve the ultimate shear strength of deep beam (Aguilar et al. 2003). On the other hand the horizontal web reinforcement is less effective in providing shear strength than the vertical web reinforcement (ACI Committee 2008). Minimum percentage of web reinforcement for strength and serviceability is $0.30 \%$ (Birrcher et al. 2013). Fig. 3 shows the benefits of distribution of horizontal web reinforcement. Shear strength is plotted on columns whereas; named as per distribution and percentage of horizontal shear reinforcement. $0.30 \%$ distribution in 0.30 times depth (0.30d) exhibits high strength over $0.20 \%$ distribution in $0.30 \mathrm{~d}$ and uniformly distributed over the depth.

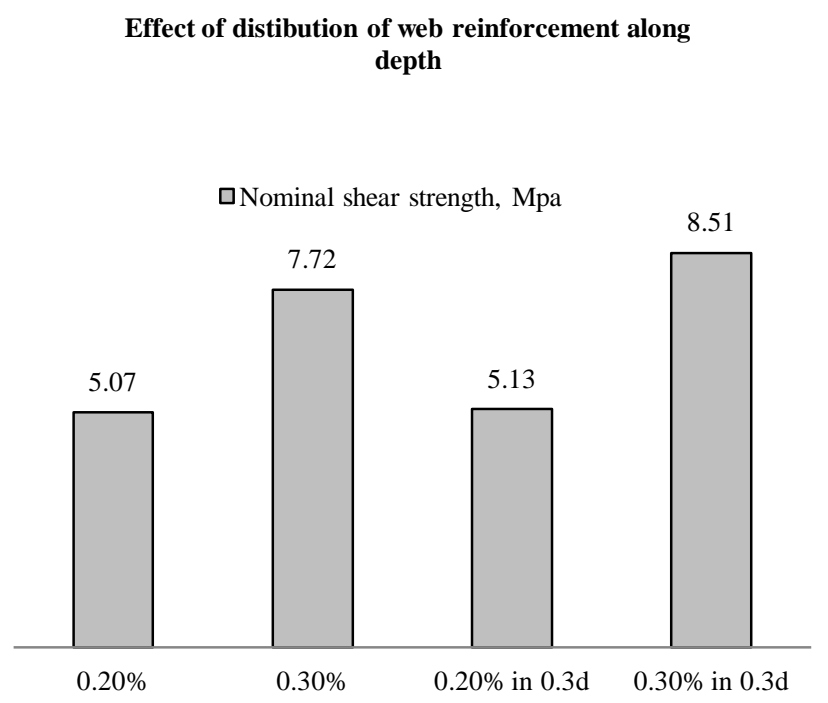

Fig. 3 Effect of distribution of horizontal web reinforcement on shear strength (Rao and Prasad 2010)

\subsection{Effect of Aggregate Interlock}

Shear strength is size independent when the contribution of aggregate interlock in the shear capacity is negligible (Walraven and Lehwalter 1994). There is no significant influence of the maximum particle diameter, grading curve and type of aggregate on the shear strength.

2.6 Effect of Shear Span-to-Depth Ratio and Effective Span-to-Depth Ratio

\subsection{Effect of Length of Loading or Bearing Plates}

Reserve strength and normalised shear strength decrease when $\mathrm{a} / \mathrm{d}$ increases. The fact holds good for fiber reinforced concrete deep beams, where the fibers used as an alternative for tension reinforcement (Andermatt and Lubell, 2013) and web reinforcement (Madan et al. 2007). Flexural behaviour was dominated when shear span-to-depth ratio is greater than 1.0 and increasing effective span-to-depth ratio (Tan et al. 1995). While the a/d ratio increases, shear failure mode seems to be combined with flexure and with high $1_{\mathrm{e}} / \mathrm{d}$ ratio flexure failure mode was predominant. The modes of failure either shear compression or shear tension is determined by shear span-to-depth ratio (Shin et al. 1999). Fig. 4 (a) and (b) depicts clearly that shear span-to-depth ratio is highly influencing parameter of deep beams shear strength. In Fig.4 (a) there is an asymptotic decrease in shear strength when the shear span-to-depth ratio increases.

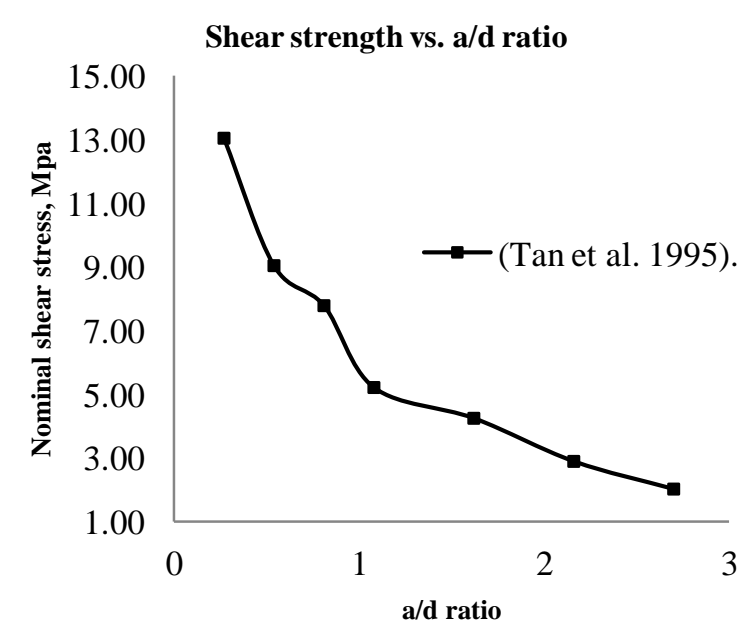

(a)

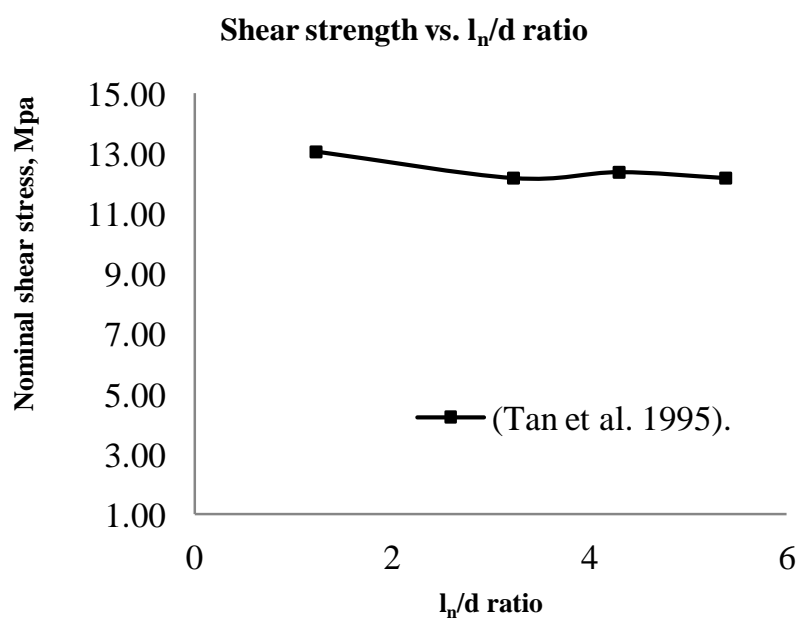

(b)

Fig. 4 Influence of shear span-to-depth ratio (a) and effective span-to-depth (b) ratio on shear strength 
A CCC (Compression-Compression-Compression) or CCT (Compression-Compression-Tension) node, tri-axially confined by surrounding concrete, can achieve bearing stresses that are much higher than the compressive strength of concrete. No evidence of reduction in shear strength when there was a reduction in width of load or support-bearing plate (Tuchscherer et al. 2010).

\subsection{Effect of Distribution of Web Reinforcement in Web}

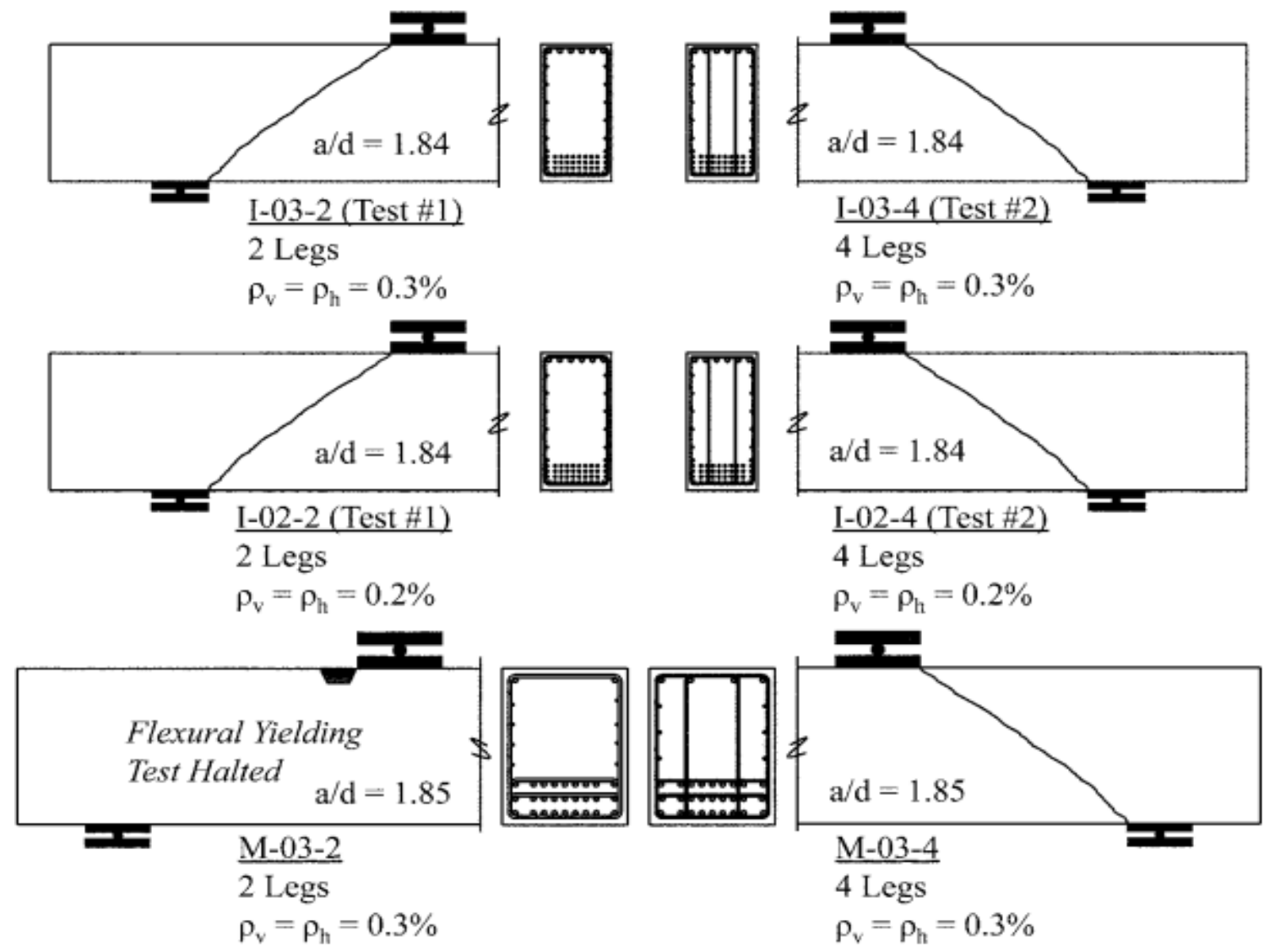

Fig. 5 Distribution of stirrups in web (Tuchscherer et al. 2011)

Effect of ditribution of reinforcement in web on the shear strength

- Shear strength of deep beams (Tuchscherer et al. 2011)

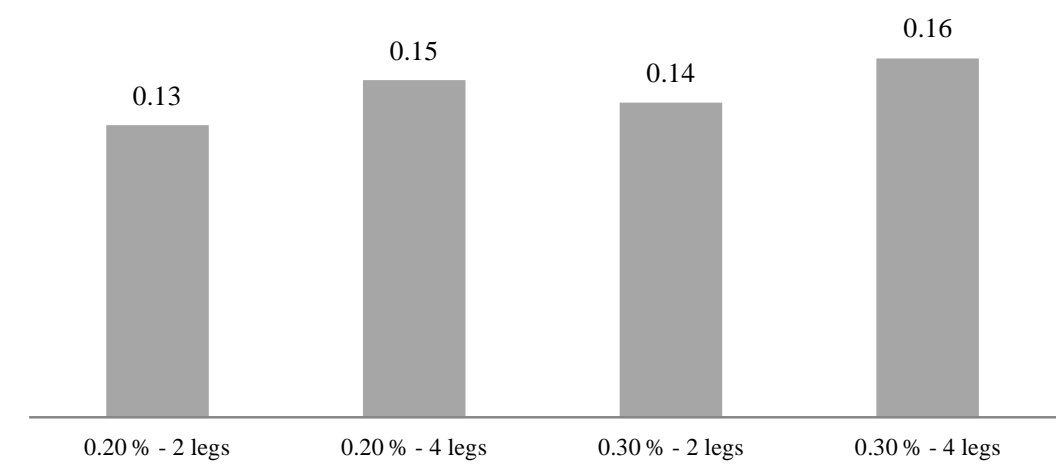

Fig. 6 Effect of distribution of stirrups in web on shear strength (Tuchscherer et al. 2011) 
Beams with and without distributed stirrups across the web is shown in fig. 5. Closely spaced stirrups in web did not enhance shear capacity or serviceability performance (Tuchscherer et al. 2011). Fig. 6 shows the shear strength of four tests on the first two beams of Fig. 5. Besides, Fig. 6 gives a clear depiction about the effect of distribution of stirrups on the shear strength. Columns in Fig. 6 are named as percentage of web reinforcement and legs of stirrups.

Web reinforcement had no influence on the magnitude of diagonal cracking strength (Zhang and Tan 2007). Web reinforcement provided vertically was most effective than the horizontal. Orthogonal reinforcement exhibited good control over diagonal cracking, enhanced shear strength and increased beam stiffness (Tan et al. 1997).

\subsection{Effect of Side Cover}

Influence of the side cover thickness on shear strength of beams was reported (Rahal, 2007). Consequence of the thick side cover tension face corner portion crushed on the other hand intact vertical side. Thickness of the side cover increases number of diagonal crack decreases conversely no effect on the width of the diagonal cracks. Spalling of concrete supposed to get in beams with high strength and large thickness web cover. The fact is that no spalling will occur until code predicted ultimate load hence reduction in the shear strength was not recommended.

Effect of side cover on the shear strength of beams

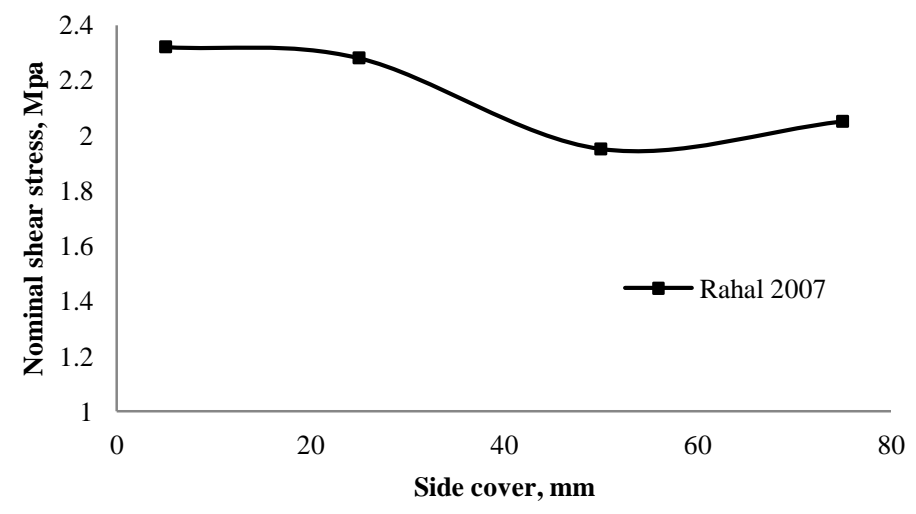

Fig. 7 Effect of side cover on the shear strength of beams (Rahal, 2007).

\subsection{Size Effect in RC Deep Beams}

Primary cause for the size effect is inappropriate adoption of the shear transfer concept subsequently; secondary cause is depends on geometry of the strut and the spacing and diameter of the web reinforcement (Tan and Cheng 2006). Strut geometry and boundary conditions was postulated as influencing factors (Zhang and Tan 2007)

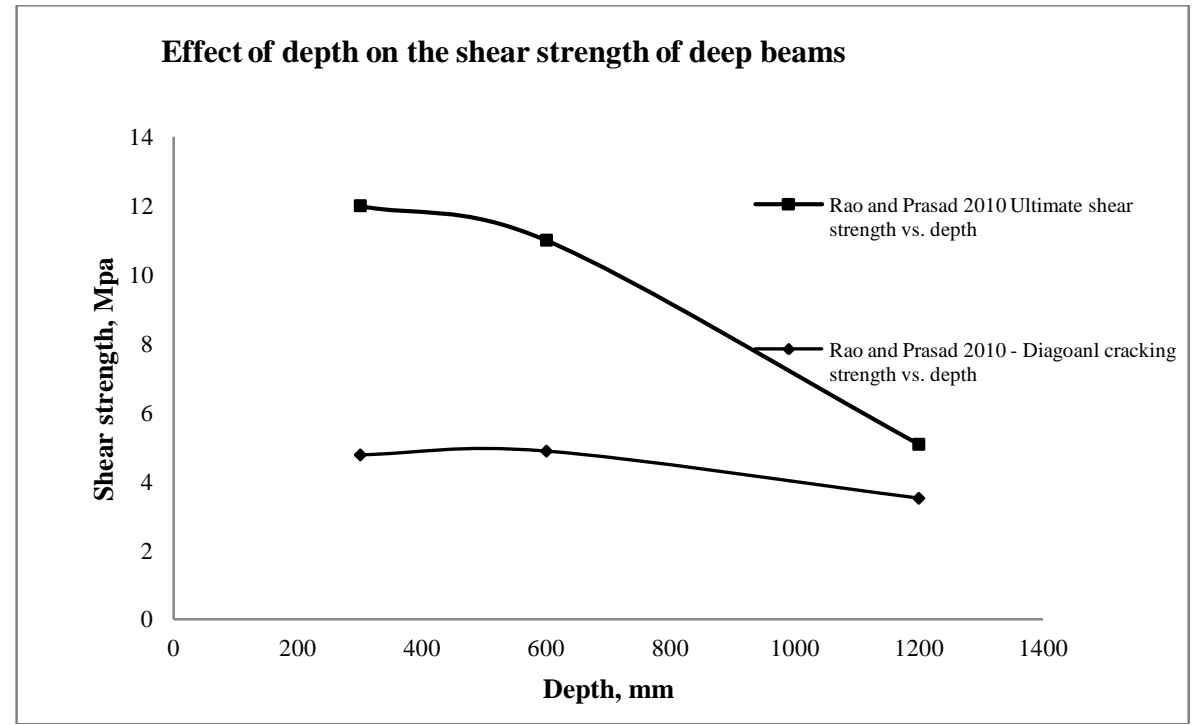

(a) Effect of depth on the ultimate and diagonal cracking shear strength of deep beams (Rao and Prasad 2010) 


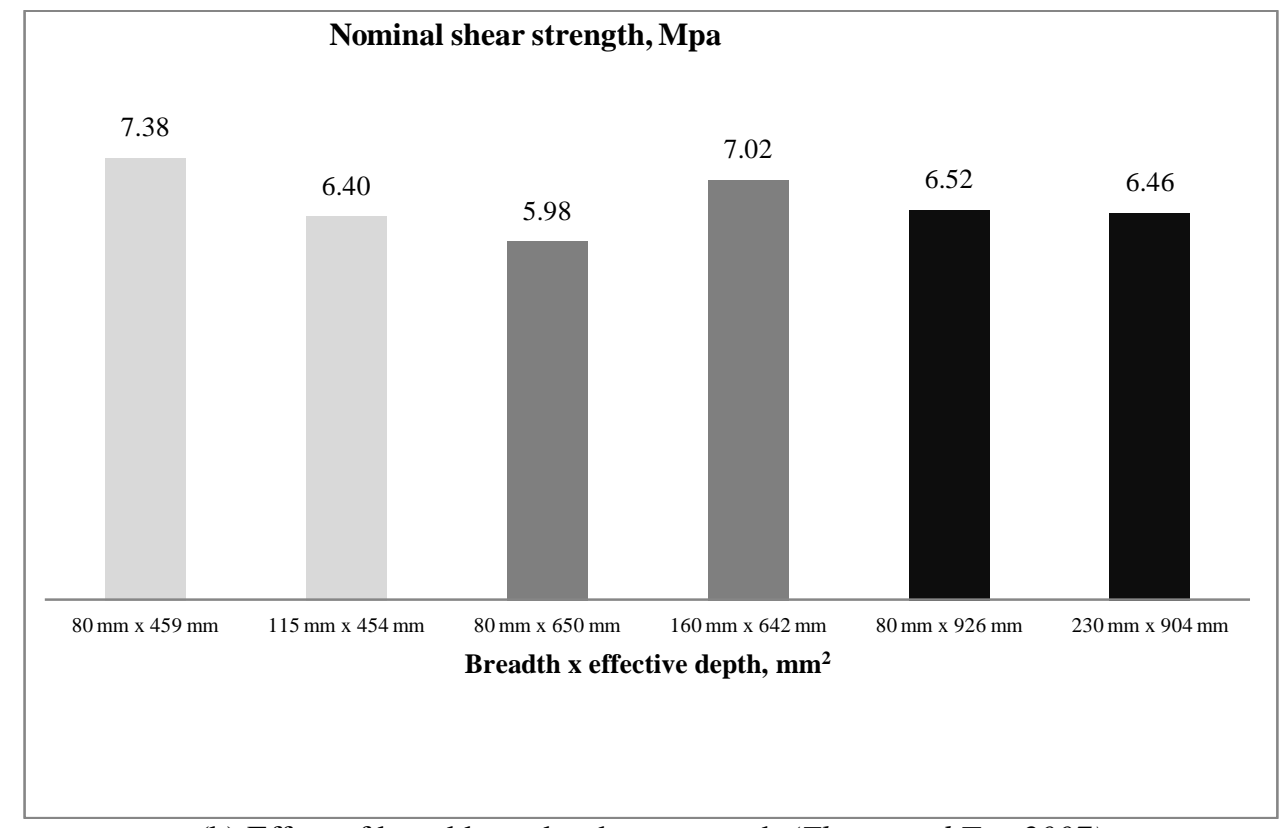

(b) Effect of breadth on the shear strength (Zhang and Tan 2007)

Fig. 8 Effect of size on shear strength of deep beams

Effect of breadth and depth on the shear strength is shown in Figs. 8(a) and (b). It is evident from Fig. 8(a) and (b) that beam width has no influence on the shear strength of deep beams (Zhang and Tan 2007) on the other hand member depth increases shear strength decreases (Rao and Prasad, 2010). Ultimate load is size dependent whereas; diagonal cracking load is size independent.

The conventional definition for shear stress $\mathrm{V}_{\mathrm{u}}$ /bd is not appropriate because of arch action. This concept was borrowed from steel I beams with uniform shear stress distribution. Uncracked concrete depth resist the shear stress on the other hand shear tran sfer in the cracked potion is negligible. Randomness of material strength, interface shear transfer and unintended out of plane deflection are some of reasons stated for size effect (Tan and Cheng 2006). Incorporating size-effect, models are proposed (Rao and Sundaresan 2012, Zhang and Tan 2007, Tang et al. 2004, Rao and Sundaresan 2014 and Rao and Injaganeri 2011).

\subsection{Normal Strain Profile and Shear Strain Distribution of Deep Beams}
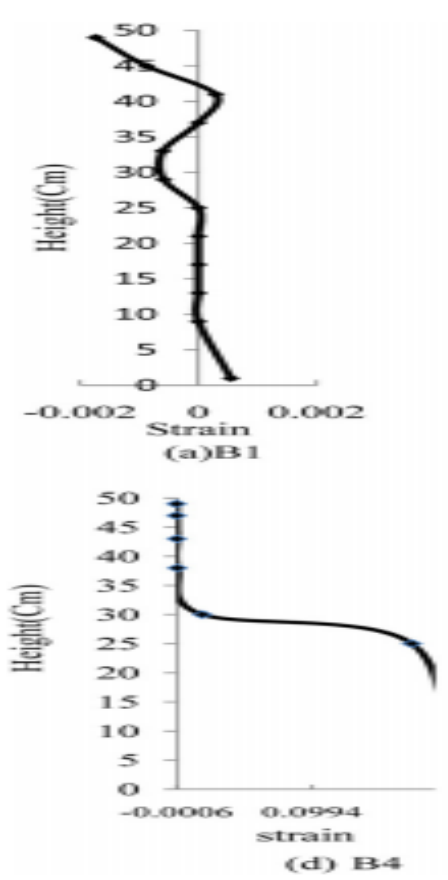
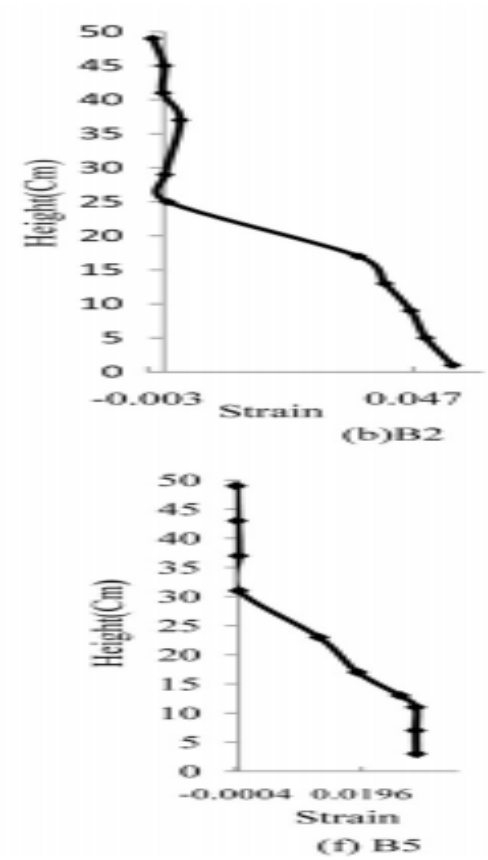
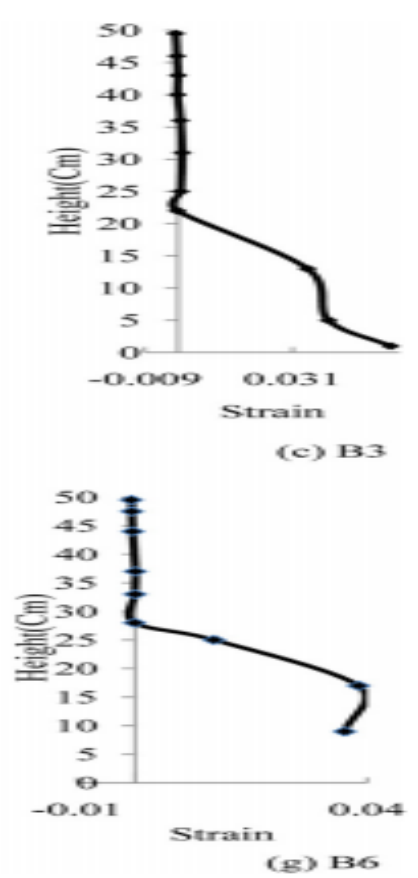

Fig. 9 Normal strain profiles of reinforced concrete deep beams (Mohammadhassani et al. 2012) 


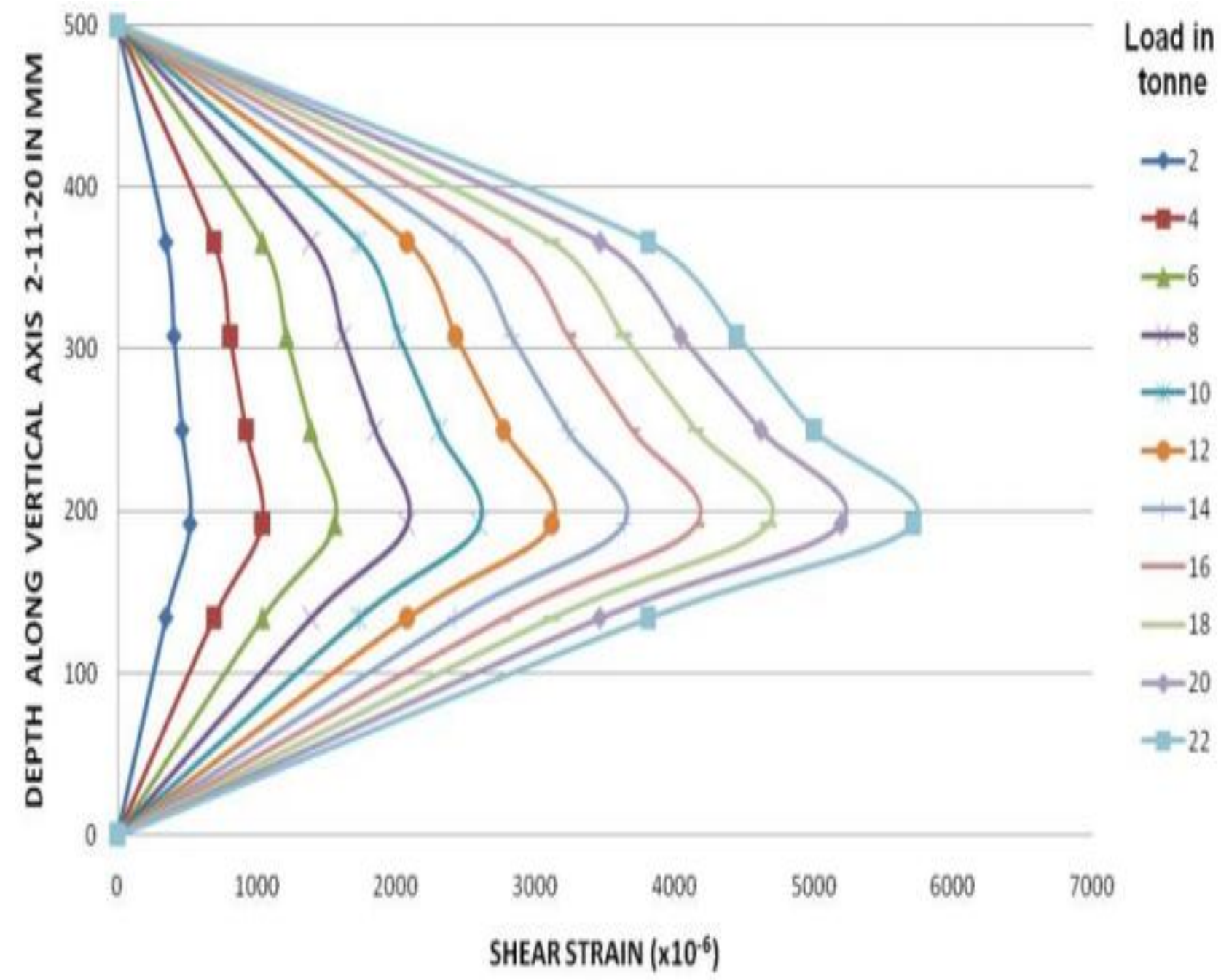

Fig. 10 Shear strain distribution of reinforced concrete deep beams (Patel and Pandya 2010)

Deep beams have more than one neutral axis (Mohammad et al. 2011). Normal strain profiles of beams with different tension reinforcement ratios are shown Fig. 9. To equilibrate the tie forces the neutral axis is closer to the extreme compression fiber. Deep beams exhibit lower strain in the extreme compression fiber. Maximum compressive strain of high strength concrete deep beams is 0.002 (Mohammadhassani et al. 2012). Shear strain distribution along the depth at different load stages level is shown in Fig. 10. Deep beams exhibit D shape shear strain profile (Patel and Pandya 2010).

\subsection{Modes of Failure}

Fig. 11 to Fig. 13 shows the failure modes of deep beams. Shear compression (Fig. 11(e)) (Andermatt and Lubell, 2013, Zhang and Tan, 2007), local crushing near the support or loading points (Fig. 11(a)) (Mohammadhassani et al. 2014, 2012 and 2013), compression strut failure (Fig. 11(c)) (Mohammadhassani et al. 2011). In Self compacting concrete (Choi et al. 2012) and prestressed concrete deep beams (Tan et al. 1999) failure mode is shear compression (Fig. 11(e)). 20 to $35 \%$ of ultimate strength was the diagonal cracking strength $\mathrm{V}_{\mathrm{cr}}$. Serviceability strength ranges between 30 to $50 \%$ of ultimate strength. While the a/d ratio increased, shear failure mode was mixed with flexure and with high effective span-to-depth ratio flexure failure mode was predominant (Tan et al. 1995). When the a/d ratio tended to 2.0 change in mode of failure from shear compression to shear tension (Shin et al. 1999). 


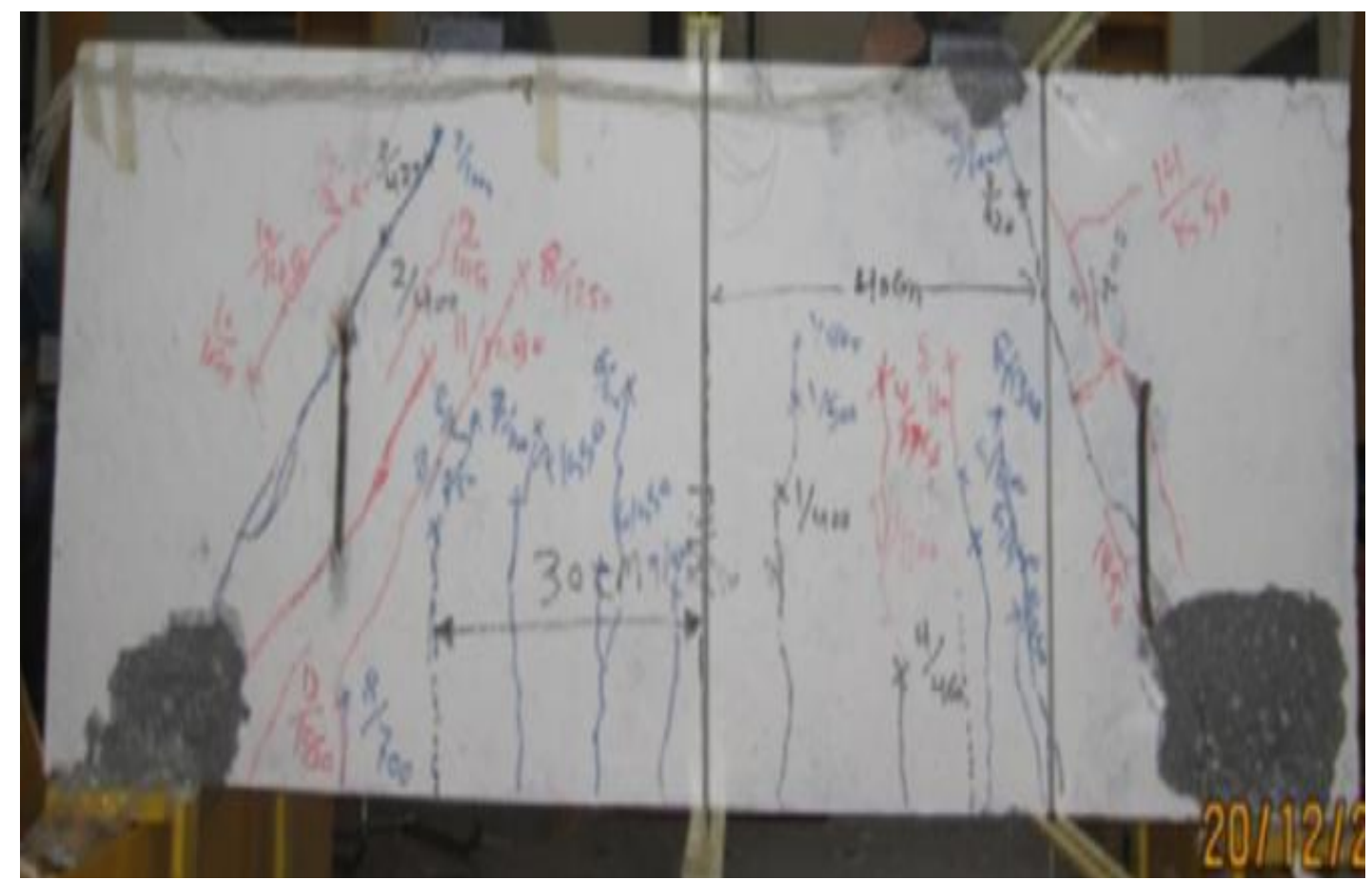

(a) Local crushing at the support points (Mohammadhassani et al. 2012)

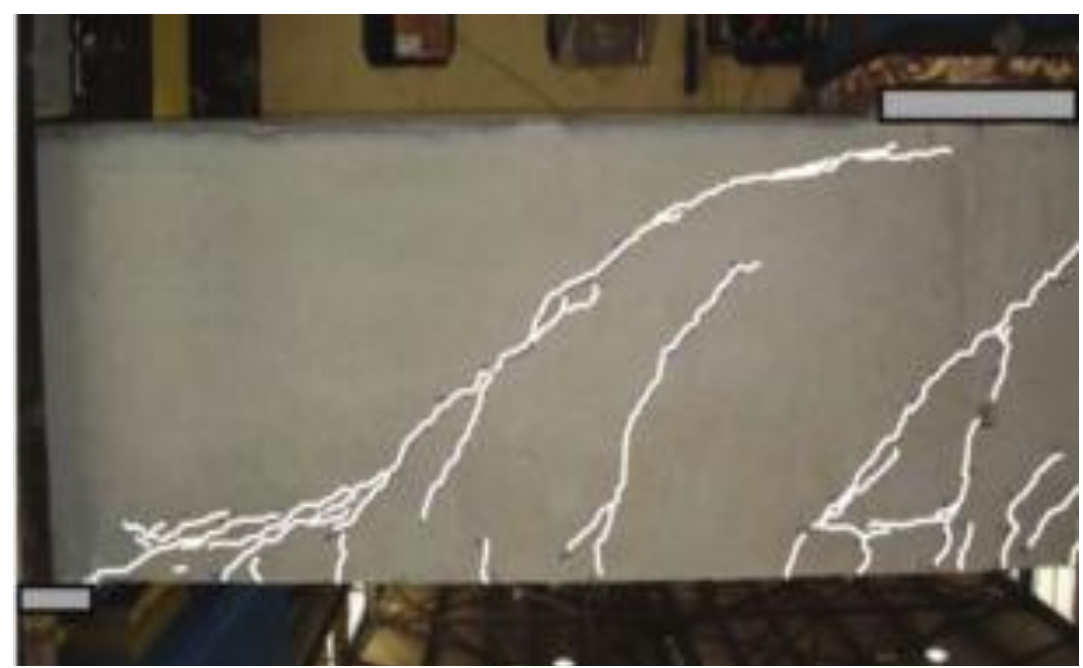

(b) Diagonal tension failure (Birrcher et al. 2013)

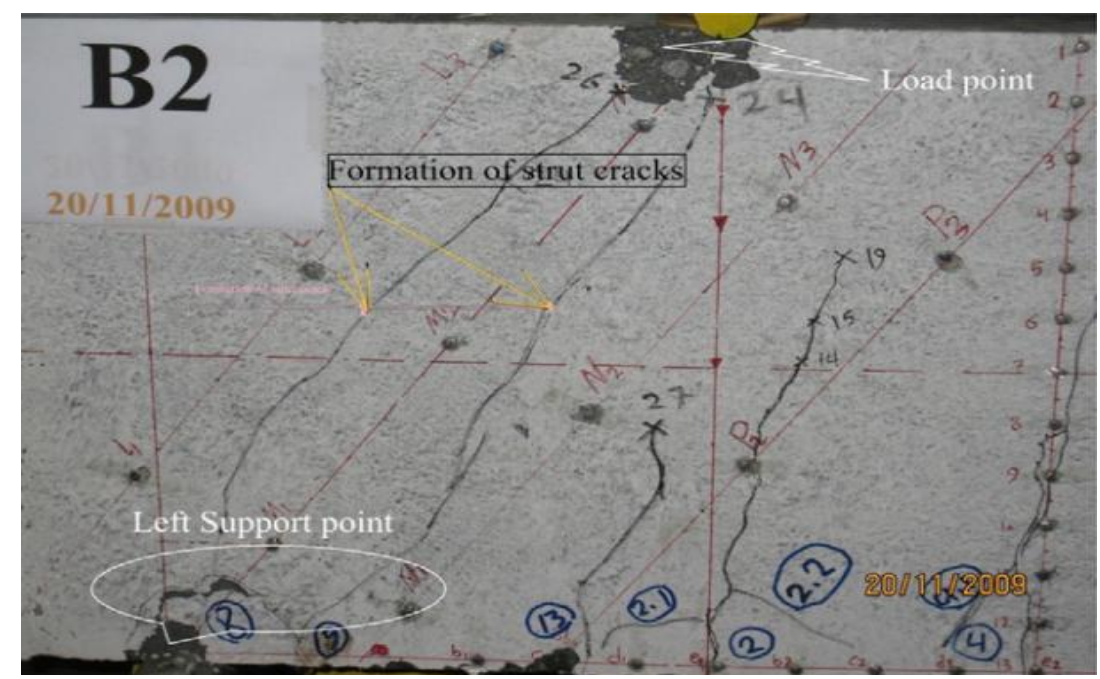

(c) Strut failure (Mohammadhassani et al. 2012) 


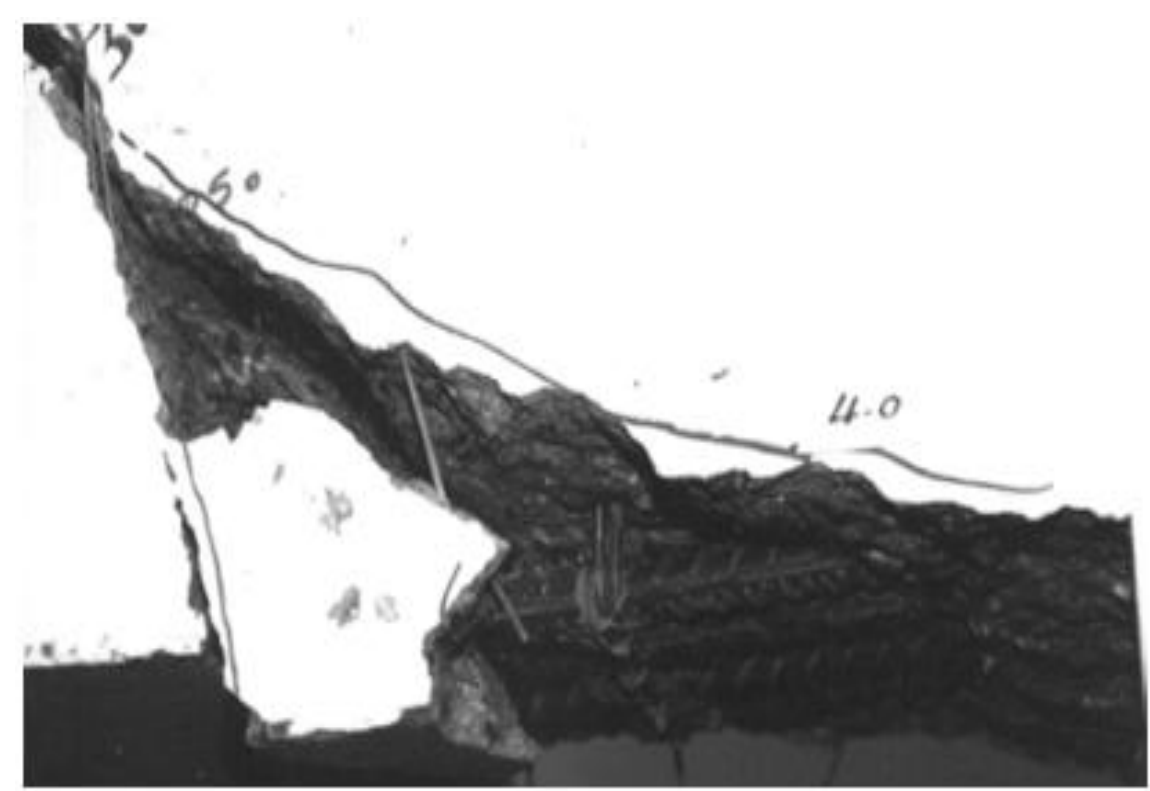

(d) Spalling of concrete in beam with $75 \mathrm{~mm}$ cover thickness (Rahal, 2007)

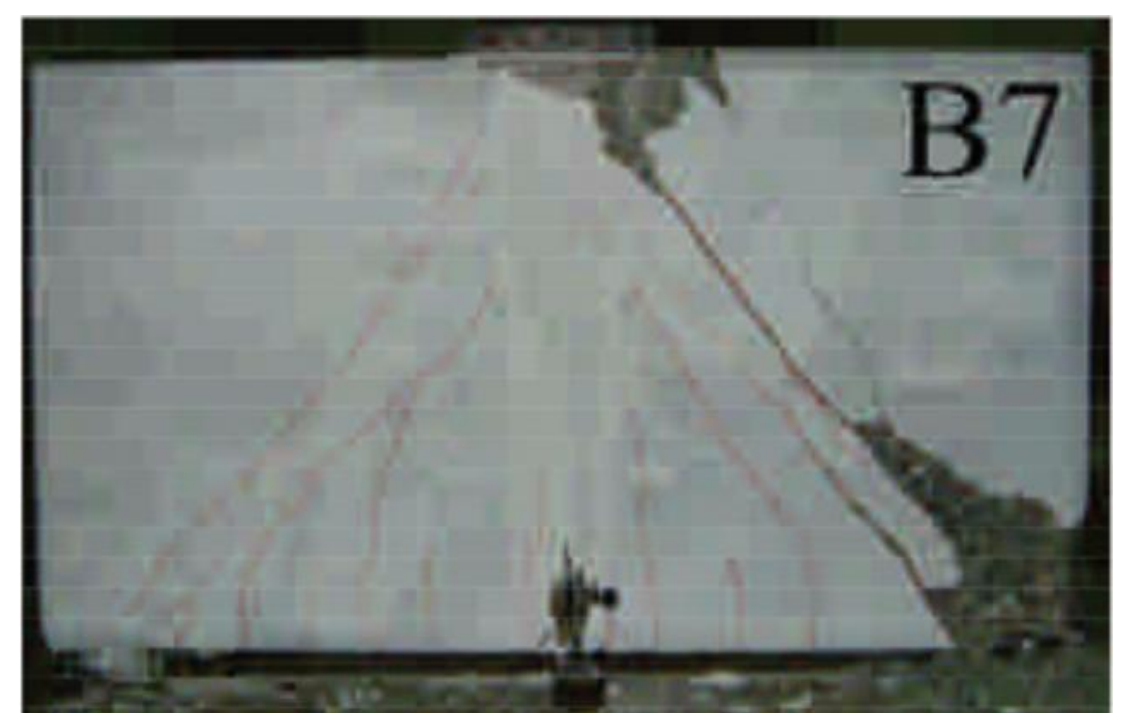

(e) Shear compression failure (Lu et al. 2013)

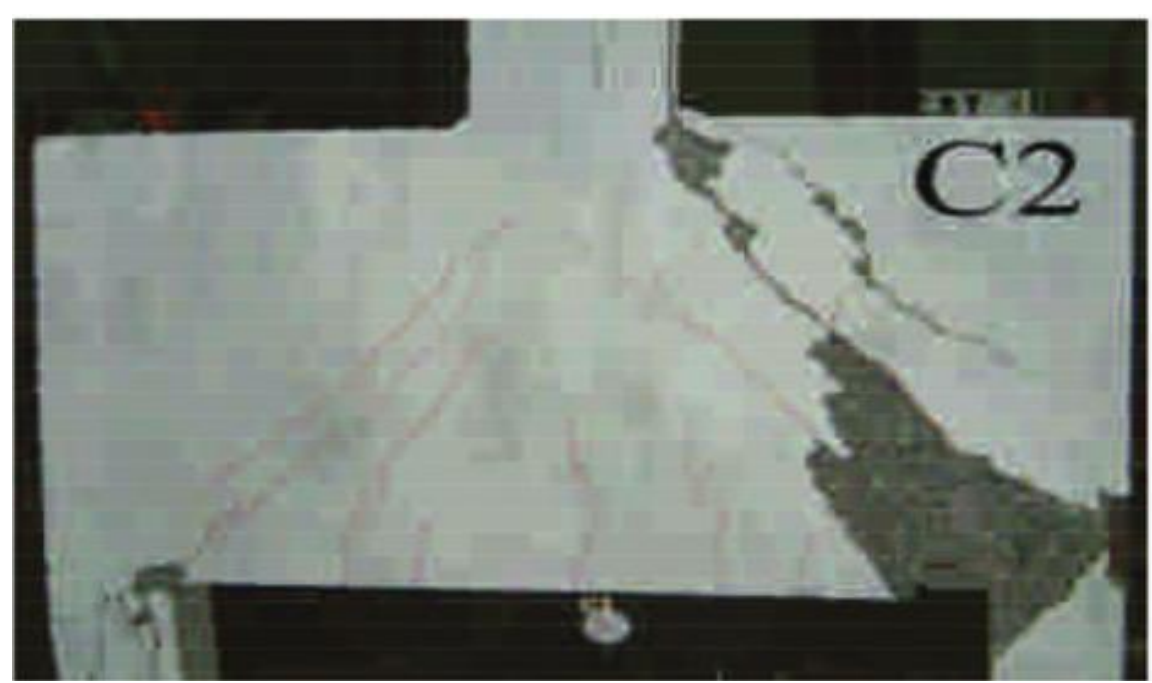

(f) Support deformation of deep beams supported by column (Lu et al. 2013)

Fig. 11 Modes of failure of deep beams 
Diagonal tension failure (Fig. 2 (b)) of deep beams affirmed by no concrete crushing was observed in critical shear span region. Axial stiffness of support plates are more than concrete columns. Consequently, support deformation (Fig. 2 (f)) of deep beams supported by column is more when compared to local crushing near support. Strut failure is the common mode of failure in deep beams. Spalling of concrete may occur due to excessive cover as show in Fig. 2 (d).

\subsection{Failure Modes of Fiber Reinforced Concrete Deep Beams}

Shear compression, diagonal tension and strut failure are the common modes of failure in conventional and fiber reinforced concrete deep beams are shown in Figs. 12 and 13. In addition to the aforementioned types of failure, fiber reinforced concrete deep beams has exhibit a distinguished mode of failure is flexural compression (Fig. 12(a)) (Andermatt and Lubell 2013). Beams with steel fibers or combination of steel fiber and polypropylene fibers can be used as replacement of web reinforcement failure modes are shown in Figs. 13(a) and (b).

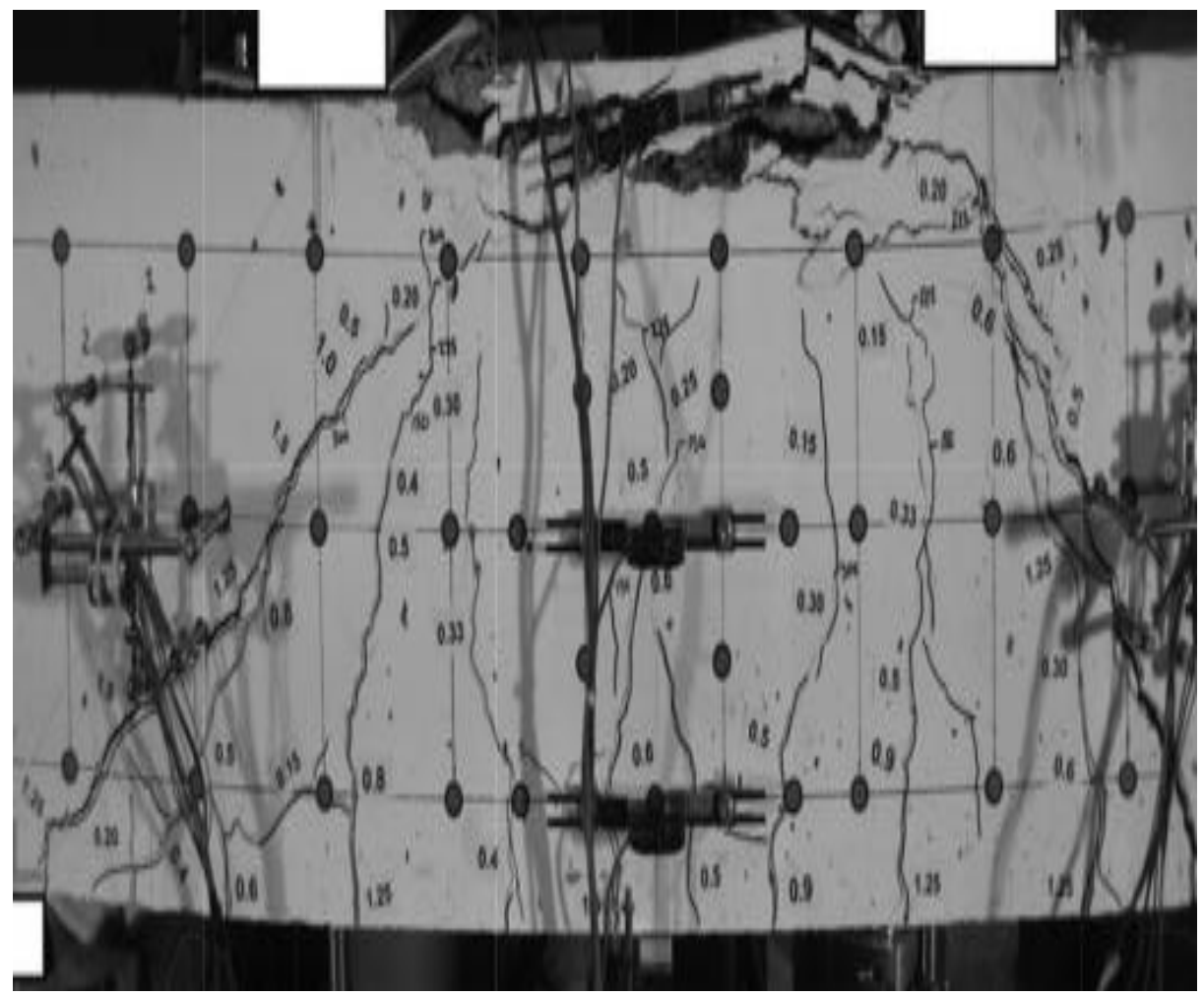

(a) Flexural compression failure

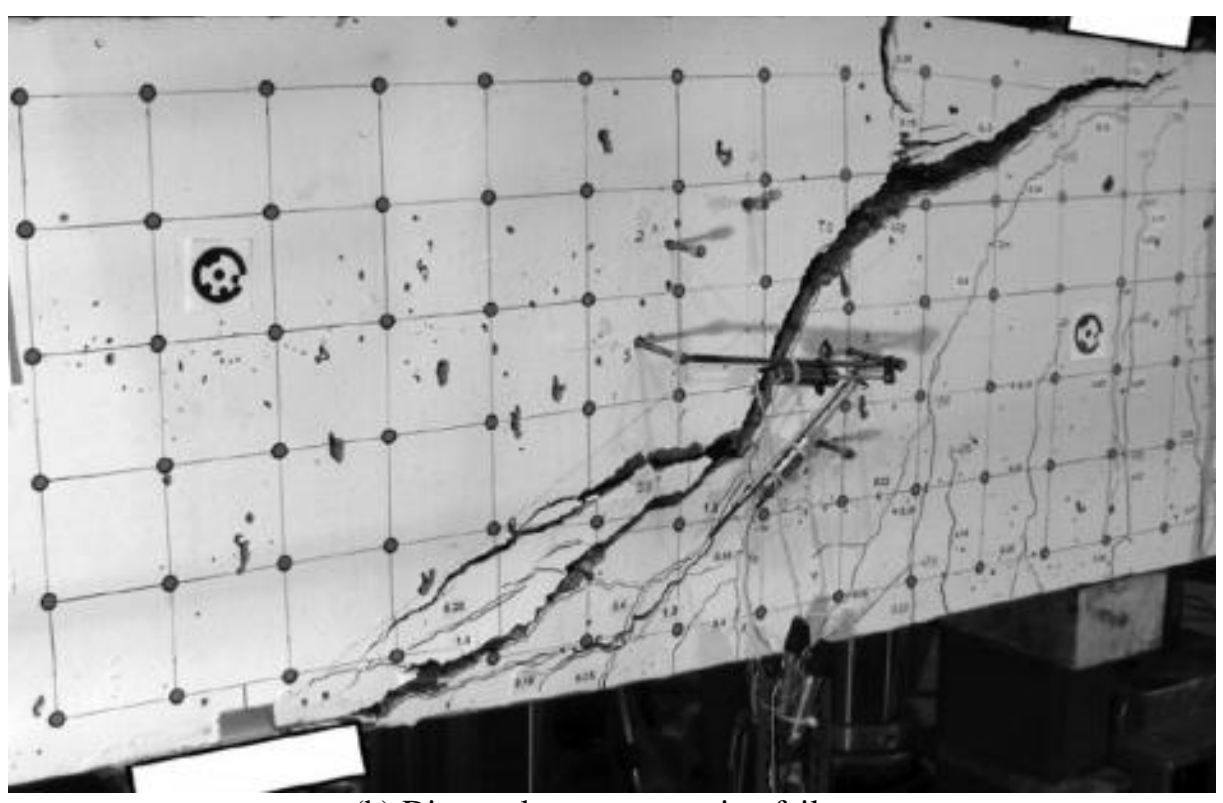

(b) Diagonal concrete tension failure 


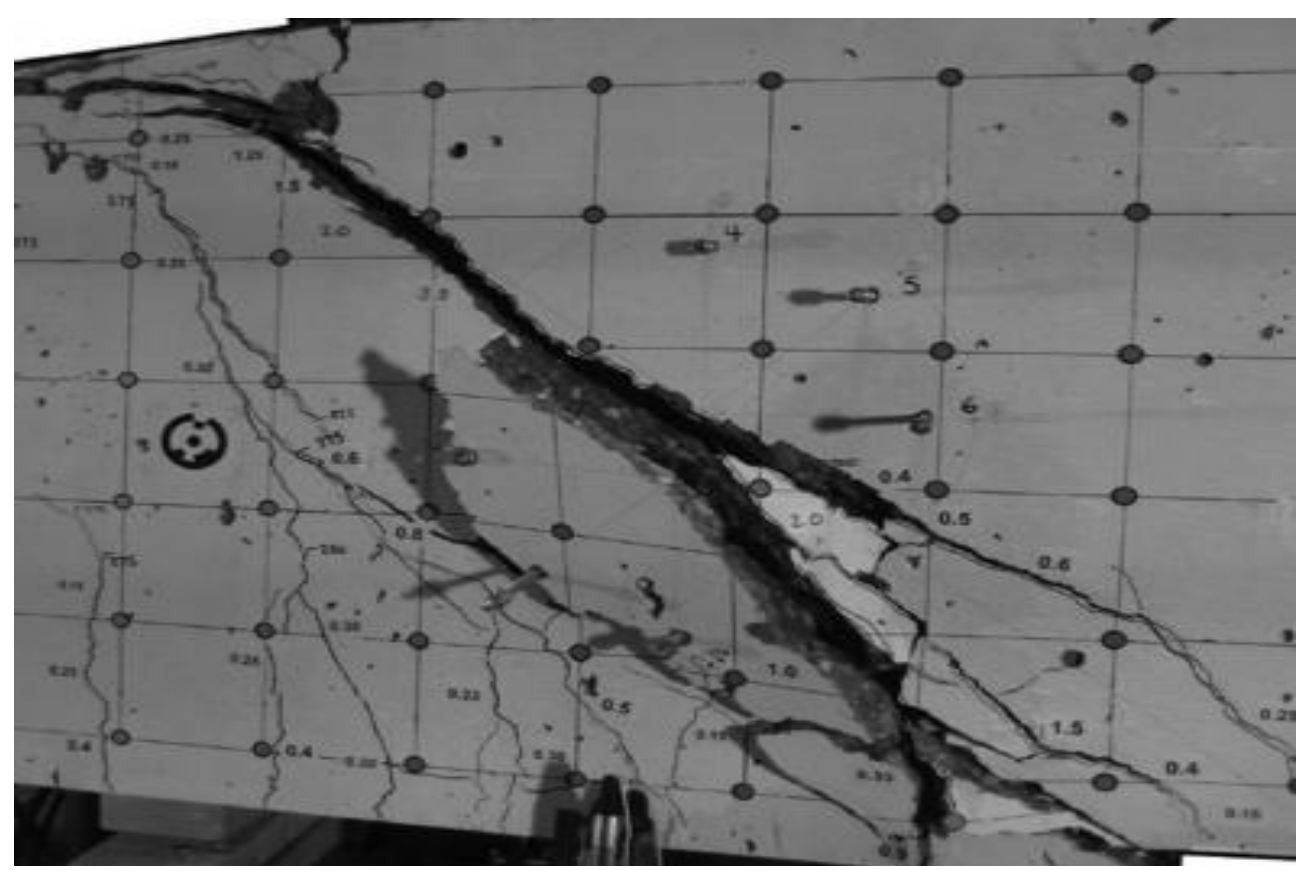

(c) Compression strut failure

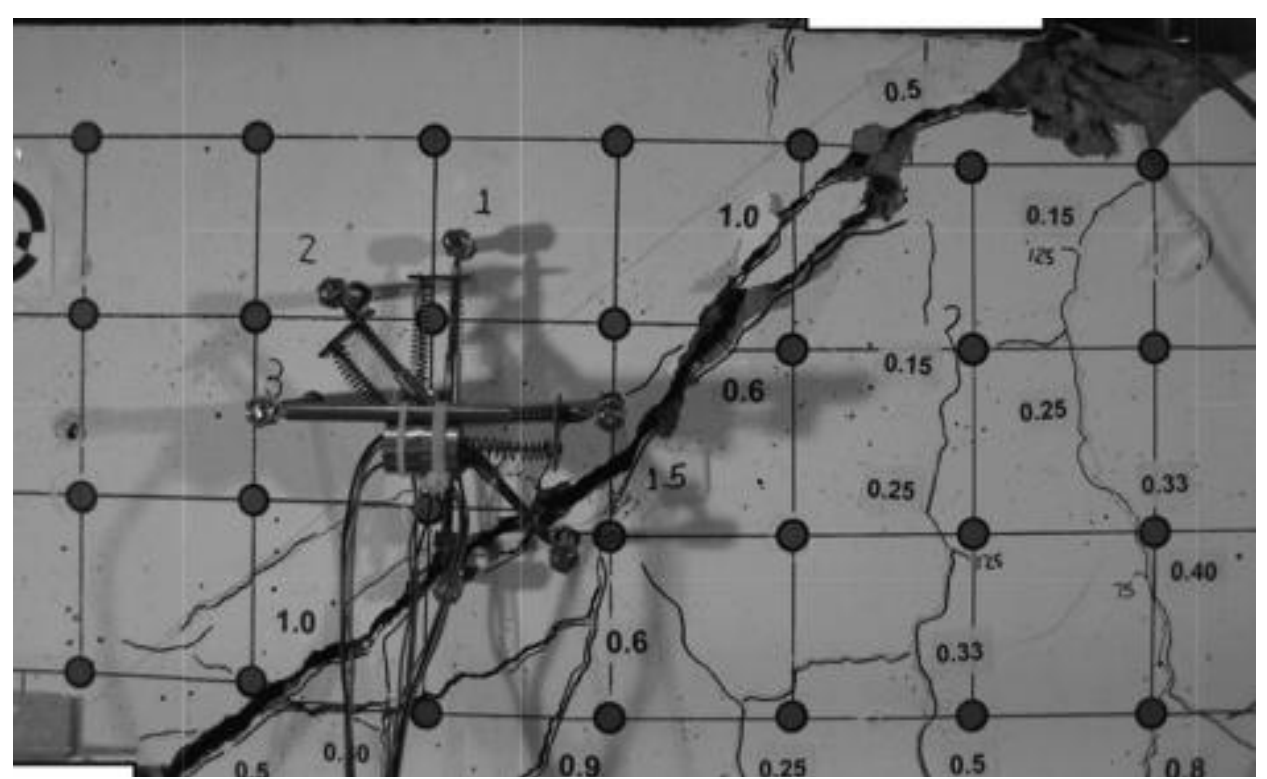

(d) Shear compression failure

Fig. 12 Failure modes of deep beams reinforced with polymer bars (Andermatt and Lubell 2013)

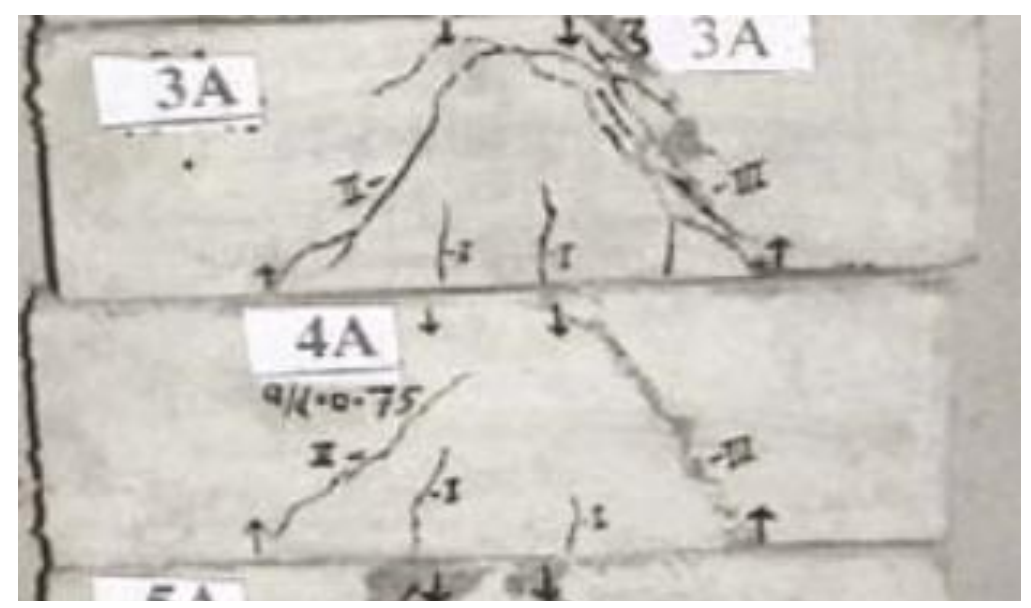




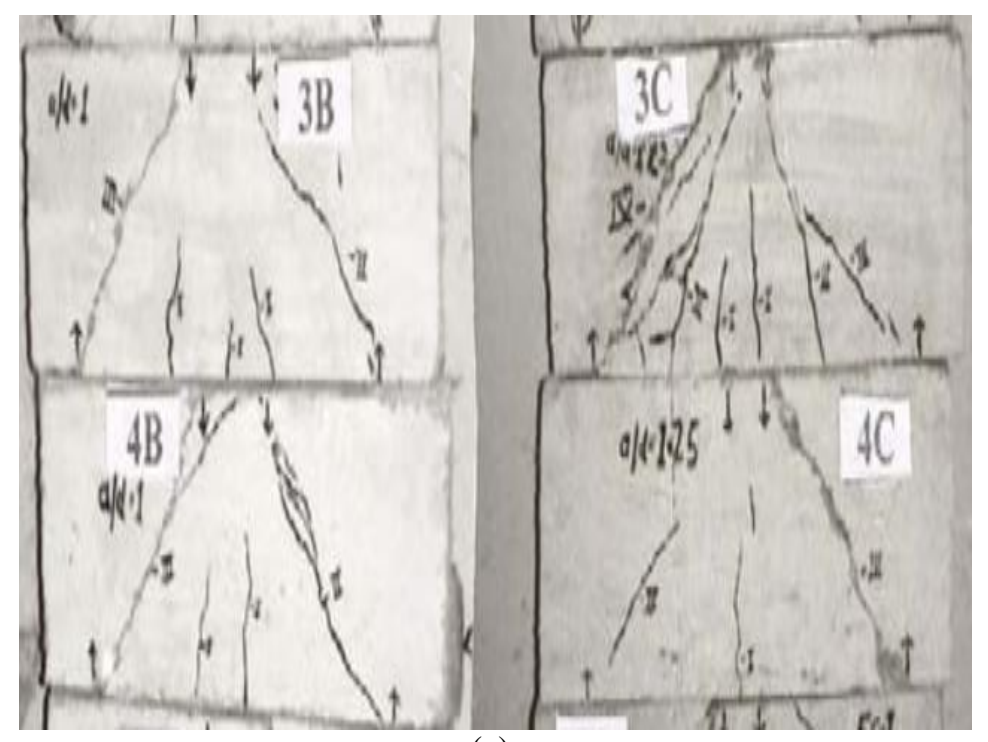

(a)

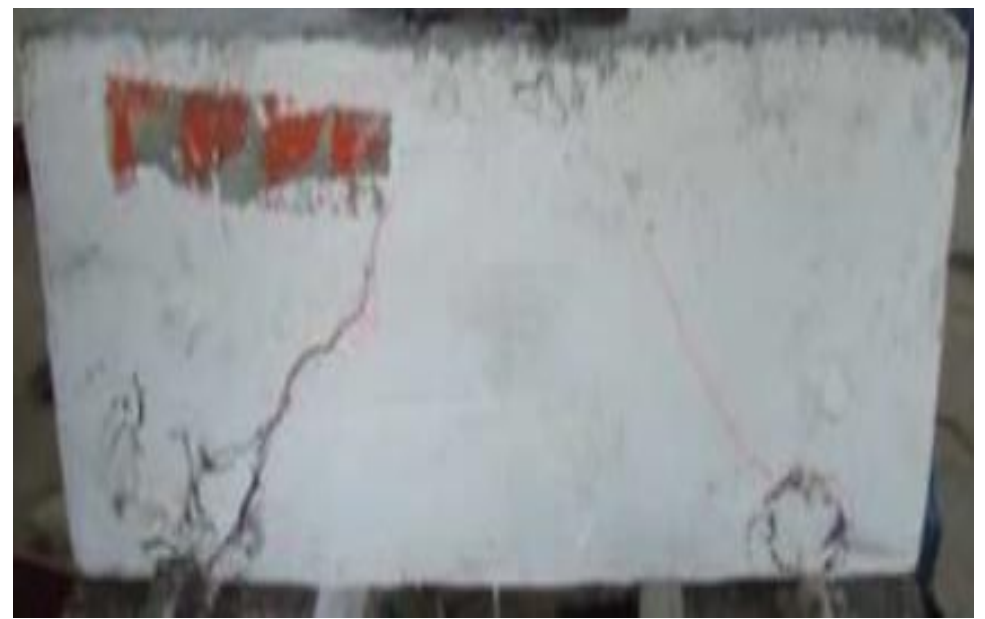

(b)

Fig. 13 Failure modes of deep beams (a) shear reinforcement replaced with steel fiber (Madan et al. 2007) and (b) combination of steel and poly-propylene fiber (Raj and Rao 2013).

\section{INTRODUCTION TO 3D PANELS AS DEEP BEAMS}

Recent times, 3D panels are being extensively preferred as roof, wall and other structural or non-structural elements. It consists of an inner core of polystyrene reinforced on each side with welded steel wire mesh, which will be covered by concrete. In addition, Figs. 14 (a), (b) and (c) shows side view, sectional view and isometric view of 3D steel wire panels. Under gravity as well as lateral loading, these elements are subjected to in-plane loading.

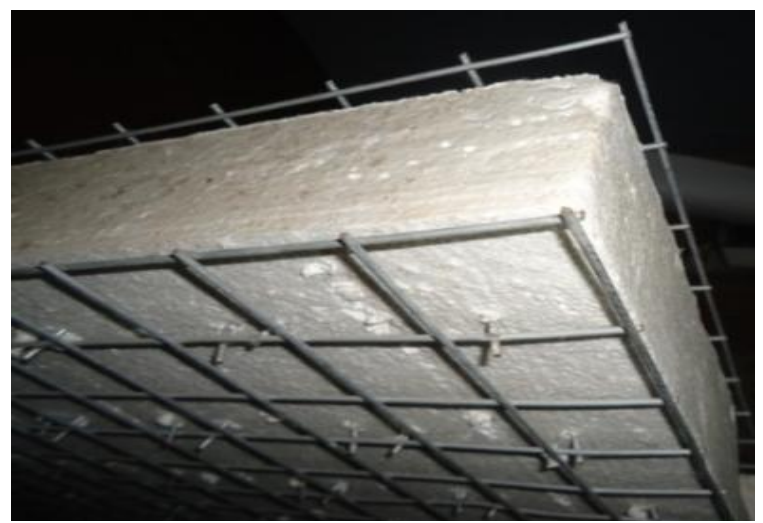

(a) 


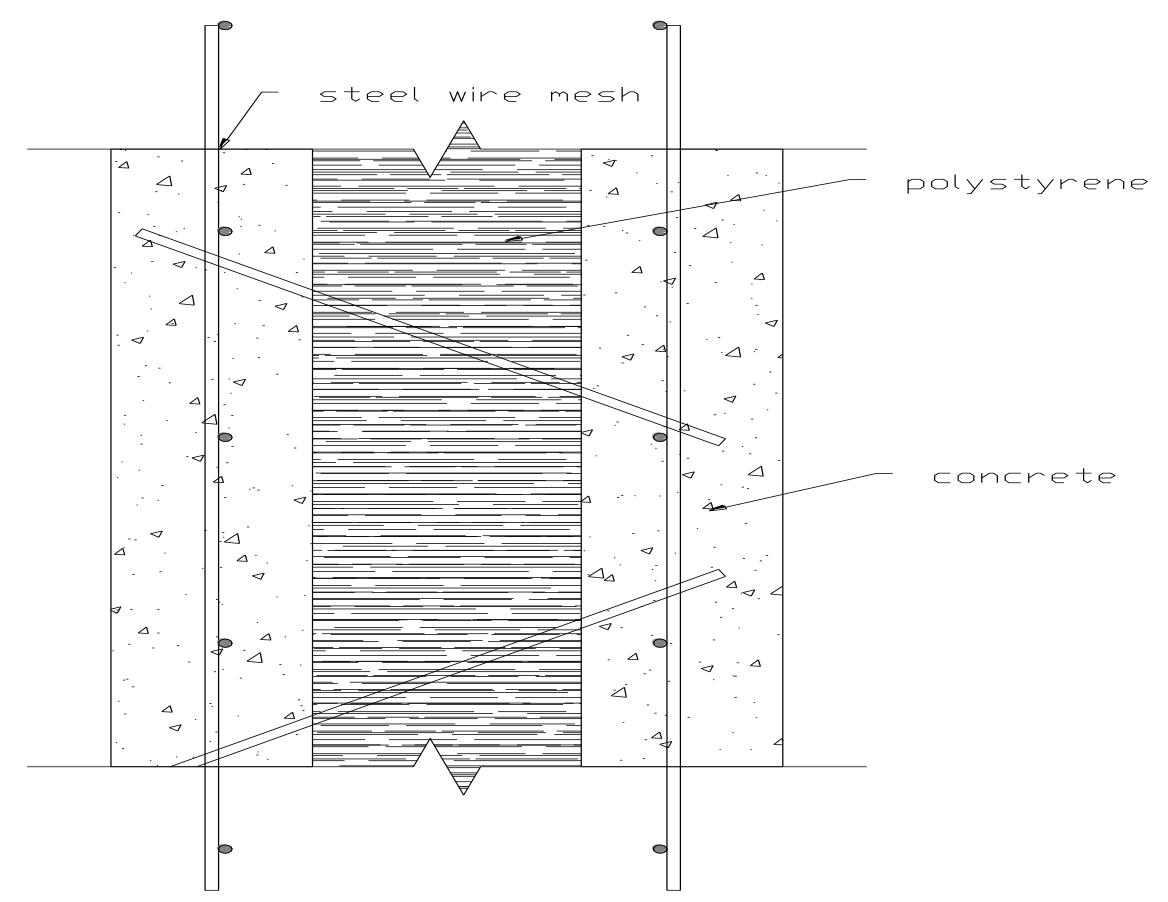

(b)

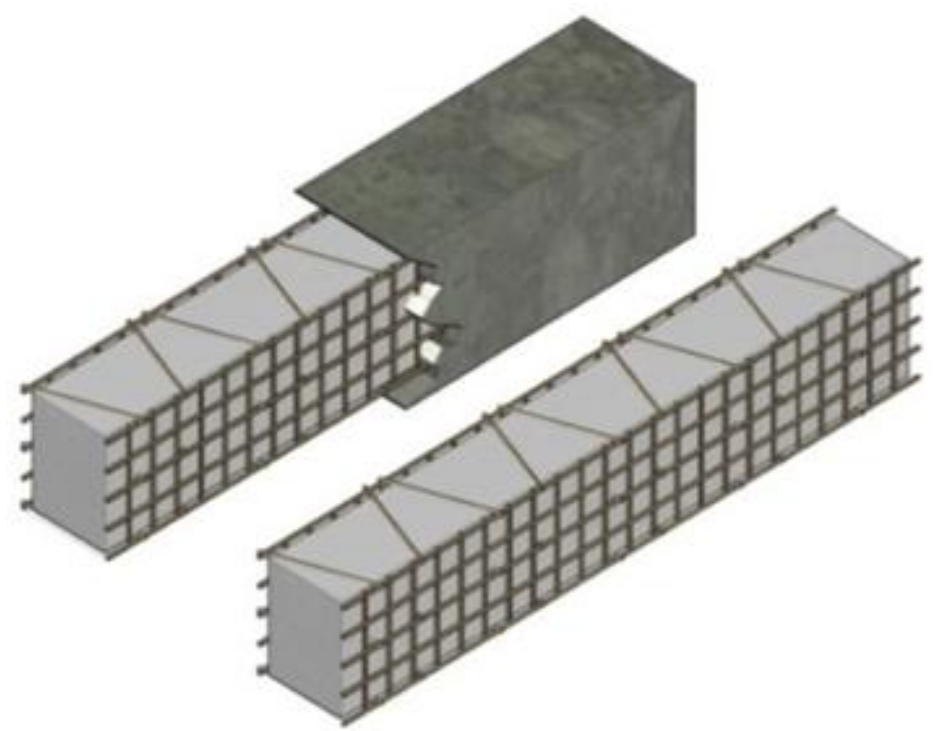

(c)

Fig. 14 Schematic diagram of 3D steel wire panels

3D panels idea has been evolved from Ferro-cement sandwich panels (Basunbul et al. 1991). Mechanical behaviour of 3D wall panels reported in static shear, bending and lateral loads (Kabir 2005)(Rezaifar et al. 2008). Tension failure was observed in lower layer of concrete and the crack propagates to the upper layer. Crushing of concrete causes instability to the system.

In flexure sandwich panels behaves as semi-composite (Gara et al. 2012). The length, height, thickness of panel and polystyrene, type of polystyrene (undulated or plain) and top and bottom concrete thickness are the parameters considered for the strength based study. Panels exhibit low slip. Simple analytical formulas were proposed to estimate the bending moments at initial cracking and ultimate failure. Double steel connectors can enhance flexural capacity (Mohamad et al. 2014). Panels serviceability need to be evaluated (Salmon et al. 1998). Carbon fiber can be used as connectors for the sandwich panels (Insel et al. 2006).

Boundary elements are portions along the wall edges that are strengthened by longitudinal and transverse reinforcement. Though they may have the same thickness as that of the wall web, it is advantageous to provide them with 
greater thickness (Medhekar and Jain 1993). Boundary elements can be used to enhance the flexural capacity (Mostofinejad and Mohammadi Anaei 2012). To increase the stiffness and to reduce the restrictions regarding the service limit state, it is important to design an efficient reinforced connection between the slabs and their supporting element. The overall contribution of the connectors to the flexural stiffness of the slab is small (Carbonari et al. 2012).

\section{CONCLUSION}

In general, code provisions for beam capacity equations are conservative. Significantly influencing parameters are shear span-to-depth ratio, horizontal web reinforcement, vertical web reinforcement, support and load bearing plates, distribution of web reinforcement along depth, compressive strength and tension reinforcement. Least influencing parameters are width of the beam, bottom cover, side cover, aggregate size and distribution of vertical stirrups in web. Diaphragm action of 3D panels needs to be experimentally evaluated.

\section{REFERENCES}

[1] Aguilar, G., Matamoros, A. B., Parra-montesinos, G. J., Ramírez, J. A., and Wight, J. K. (2003). "Experimental Evaluation of Design Procedures for Shear Strength of Deep Reinforced Concrete Beams." (99), 539-548.

[2] Andermatt, M. F., and Lubell, A. S. (2013). "Behavior of Concrete Deep Beams Reinforced with Internal Fiber-Reinforced Polymer - Experimental Study." ACI Structural Journal, 47(110), 585-594.

[3] Arabzadeh, A., Aghayari, R., and Rahai, A. R. (2011). "International Journal of Civil Engineering Investigation of experimental and analytical shear strength of reinforced concrete deep beams." 9(3).

[4] Basunbul, I. a., Saleem, M., and Al-Sulaimani, G. J. (1991). "Flexural behavior of ferrocement sandwich panels." Cement and Concrete Composites, 13(1), 21-28.

[5] Birrcher, D. B., Tuchscherer, R. G., Huizinga, M., and Bayrak, O. (2013). "Minimum Web Reinforcement in Deep Beams." ACI Structural Journal, 26(110), 297-306.

[6] Carbonari, G., S.H.P. Cavaloro, Cansario, M. M., and Aguado, A. (2012). "Flexural behaviour of light-weight sandwich panels composed by concrete and EPS."

[7] Choi, Y. W., Lee, H. K., Chu, S. B., Cheong, S. H., and Jung, W. Y. (2012). "Shear Behavior and Performance of Deep Beams Made with SelfCompacting Concrete.” 6(2), 65-78.

[8] Committee, A. 318. (2008). Building Code Requirements for Structural Concrete ( ACI 318-08 ).

[9] Gara, F., Ragni, L., Roia, D., and Dezi, L. (2012). "Experimental behaviour and numerical analysis of floor sandwich panels." Engineering Structures, Elsevier Ltd, 36, 258-269.
[10] Insel, B. E., Olsen, M. D., Tanner, J. E., and Dolan, C. W. (2006). "Carbon Fiber Connectors for Concrete Sandwich Panels Shear transfer strength of grid connectors is evaluated." (October), 33-38.

[11] IS 456. (2000). "Plain And Reinforced Concrete Code Of Practice." (July).

[12] Kabir, M. Z. (2005). "Structural Performance of 3-D Sandwich Panels Under Shear and Flexural Loading." Scientia Iranica, 12(4), 402-408.

[13] Lu, W., Lin, I., and Yu, H. (2013). "Shear Strength of Reinforced Concrete Deep Beams." Aci Structural Journal, 55(110), 671-680.

[14] Madan, S. K., Kumar, G. R., and Singh, S. P. (2007). "Steel Fibers As Replacement Of Web Reinforcement For RCC Deep Beams in Shear." Asian Journal of Civil Engineering (Building and Housing), 8(5), 479-489.

[15] Matamoros, A. B., and Wong, K. H. (2003). "Design of Simply Supported Deep Beams Using Strut-andTie Models.” ACI Structural Journal, 72(100), 704 7012.

[16] Medhekar, M. S., and Jain, S. K. (1993). "SeismicBehaviour_Design\&DetailingofShearWalls -I: Behaviour and strength."

[17] Mohamad, N., Khalil, a. I., Abdul Samad, a. a., and Goh, W. I. (2014). "Structural Behavior of Precast Lightweight Foam Concrete Sandwich Panel with Double Shear Truss Connectors under Flexural Load.” ISRN Civil Engineering, 2014, 1-7.

[18] Mohammad, M., Zamin, M., Jumaat, B., Ghasemi, A., Hakim, S. J. S., and Najmeh, R. (2011). “An Experimental Investigation of the Stress-Strain Distribution in High Strength Concrete Deep Beams." Procedia Engineering, Elsevier B.V., 14, 2141-2150.

[19] Mohammadhassani, M., Akib, S., Shariati, M., Suhatril, M., and Arabnejad Khanouki, M. M. (2014). "An experimental study on the failure modes of high strength concrete beams with particular references to variation of the tensile reinforcement ratio." Engineering Failure Analysis, Elsevier Ltd, 41, 73-80.

[20] Mohammadhassani, M., Akib, S., Shariati, M., Suhatril, M., and Khanouki, M. M. A. (2013). "An experimental study on the failure modes of high strength concrete beams with particular references to variation of the tensile reinforcement ratio." Engineering Failure Analysis, Elsevier Ltd, (41), 73-80.

[21] Mohammadhassani, M., Zamin, M., Ashour, A., and Jameel, M. (2011). "Failure modes and serviceability of high strength self compacting concrete deep beams." Engineering Failure Analysis, Elsevier Ltd, 18(8), 2272-2281.

[22] Mohammadhassani, M., Zamin, M., Jameel, M., Badiee, H., and Arumugam, A. M. S. (2012). "Ductility and performance assessment of high strength self compacting concrete (HSSCC) deep beams: An experimental investigation." Nuclear 
Engineering and Design, Elsevier B.V., 250(2), 116-124.

[23] Mostofinejad, D., and Mohammadi Anaei, M. (2012). "Effect of confining of boundary elements of slender RC shear wall by FRP composites and stirrups.” Engineering Structures, Elsevier Ltd, 41, $1-13$.

[24] Mphonde, A. G., and Frantz, G. C. (1984). "Shear Tests of High - and Low-Strength Concrete Beams Without Stirrups." ACI Structural Journal, 32(81), 350-357.

[25] Murty, C. V. R. (2005). Earthquake Tip 23 - Why are Buildings with Shear Walls preferred in Seismic Regions?. 45-46.

[26] Patel, V. R., and Pandya, I. I. (2010). "Evaluation of Shear Strain Distribution In Polypropylene Fiber Reinforced Cement Concrete Moderate Deep Beams." International Journal of Civil and Structural Engineering, 1(3), 440-448.

[27] Rahal, K. N. (2007). "Shear Behaviour of Reinforced Concrete Beams with Variable Thickness of Concrete Side Cover." ACI Structural Journal, 18(103), 171-177.

[28] Rahal, K. N., and Al-shaleh, K. S. (2005). "Minimum Transverse Reinforcement in $65 \mathrm{MPa}$ Concrete Beams." ACI Structural Journal, 87(101), 872-878.

[29] Raj, J. L., and Rao, G. A. (2013). "Performance of RC Deep Beams with Different Combinations of Web Reinforcement." Applied Mechanics and Materials, 343, 21-26.

[30] Rao, G. A., and Injaganeri, S. S. (2011). "Evaluation of size dependent design shear strength." Sadhana, 36(3), 393-410.

[31] Rao, G. A., and Prasad, B. S. R. K. (2010). "Effect of depth and distribution of horizontal shear reinforcement on shear strength and ductility of RC deep beams function." Proceedings of FraMCoS-7, 1831-1836.

[32] Rao, G. A., and Sundaresan, R. (2012). "Evaluation of size effect on shear strength of reinforced concrete deep beams using refined strut-and-tie model." 37(February), 89-105.

[33] Rao, G. A., and Sundaresan, R. (2014). "Size Dependent Shear Strength Of Reinforced Concrete Deep Beams Based On Refined Strut-And-Tie Model." Journal of Frontiers in Construction Engineering, 3(1), 9-19.

[34] Rezaifar, O., Kabir, M. Z., Taribakhsh, M., and Tehranian, A. (2008). "Dynamic behaviour of 3Dpanel single-storey system using shaking table testing." Engineering Structures, 30, 318-337.

[35] Sahoo, K., Singh, B., and Bhargava, P. (2009). "Investigation of Dispersion of Compression in Bottle-Shaped Struts." (106).

[36] Salmon, D. C., Einea, A., Tadros, M. K., and Culp, T. D. (1998). "Full-Scale Testing of Precast Concrete Sandwich Panels." ACI Structural Journal, 32(94), 354-362.
[37] Shin, S., Lee, K., Moon, J., and Ghosh, S. K. (1999). "Shear Strength of Reinforced High-Strength Concrete Beams with Shear Span-to-Depth Ratios between 1 . 5 and 2 . 5." ACI Structural Journal, 61(96), 549-556.

[38] Smith, K. N., and Vantsiotis, A. S. (1983). "Shear Strength of Deep Beams." (79), 201-213.

[39] Tan, K. H., and Cheng, G. H. (2006). "Size Effect on Shear Strength of Deep Beams: Investigating with Strut-and-Tie Model.” Journal of Structural Engineering, 132(5), 673-685.

[40] Tan, K. H., Lu, H. Y., and Teng, S. (1999). "Size Effect in Large Prestressed Concrete Deep Beams." ACI Structural Journal, 103(96), 937-947.

[41] Tan, K., Kong, F., Teng, S., and Guan, L. (1995). "High-Strength Concrete Deep Beams with Effective Span and Shear Span Variations." ACI Structural Journal, 37(92), 395-403.

[42] Tan, K., Kong, F., Teng, S., and Weng, L. (1997). "Effect of Web Reinforcement on High-Strength Concrete Deep Beams." ACI Structural Journal, 52(94), 572-581.

[43] Tang, C. Y., Asce, A., Tan, K. H., and Asce, M. (2004). "Interactive Mechanical Model for Shear Strength of Deep Beams." (October), 1534-1544.

[44] Tuchscherer, R., Birrcher, D., Huizinga, M., and Bayrak, O. (2010). "Confinement of Deep Beam Nodal Regions.” ACI Structural Journal, 70(107), 709-717.

[45] Tuchscherer, R., Birrcher, D., Huizinga, M., and Bayrak, O. (2011). "Distribution of Stirrups across Web of Deep Beams." ACI Structural Journal, 12(108), 108-115.

[46] Vecchio, F. J., Collins, M. P., Members, and Asce. (1993). "Compression Response Of Cracked Reinforced Concrete." Journal of Structural Engineering, 119(12), 3590-3610.

[47] Walraven, J., and Lehwalter, N. (1994). "Size Effects in Short Beams Loaded in Shear." ACI Structural Journal, 57(91), 585-593.

[48] Zhang, N., and Tan, K.-H. (2007). "Size effect in RC deep beams: Experimental investigation and STM verification.” Engineering Structures, 29(12), 3241-3254. 